\title{
Transcriptome changes and polymyxin resistance of acid-adapted Escherichia coli 0157:H7 ATCC 43889
}

\author{
Daekeun Hwang ${ }^{1,2}$, Seung Min Kim³ and Hyun Jung Kim ${ }^{1,2^{*}}$ (1)
}

\begin{abstract}
Background: Acid treatment is commonly used for controlling or killing pathogenic microorganisms on medical devices and environments; however, inadequate acid treatment may cause acid tolerance response (ATR) and offer cross-protection against environmental stresses, including antimicrobials. This study aimed to characterise an Escherichia coli strain that can survive in the acidic gastrointestinal environment.

Results: We developed an acid-tolerant E. coli O157:H7 ATCC 43889 (ATCC 43889) strain that can survive at pH 2.75 via cell adaptation in low pH conditions. We also performed RNA sequencing and qRT-PCR to compare differentially expressed transcripts between acid-adapted and non-adapted cells. Genes related to stress resistance, including $k d p A$ and $b s h A$ were upregulated in the acid-adapted ATCC 43889 strain. Furthermore, the polymyxin resistance gene arnA was upregulated in the acid-adapted cells, and resistance against polymyxin B and colistin (polymyxin E) was observed. As polymyxins are important antibiotics, effective against multidrug-resistant gram-negative bacterial infections, the emergence of polymyxin resistance in acid-adapted E. coli is a serious public health concern.

Conclusion: The transcriptomic and phenotypic changes analysed in this study during the adaptation of $E$. coli to acid environments can provide useful information for developing intervention technologies and mitigating the risk associated with the emergence and spread of antimicrobial resistance.
\end{abstract}

Keywords: E. coli O157:H7, Polymyxin resistance, Acid adaptation, Whole genome sequencing, Transcriptome analysis

\section{Background}

Acid treatment is commonly used for the control or elimination of pathogenic microorganisms on the surface of medical devices or in environments, as well as in treatment of wastewater and food, as most microorganisms, including pathogenic bacteria, grow optimally at a $\mathrm{pH}$ range of 5-9 [1-3]. For instance, in pharmaceutical and medical environments, hypochlorous acid is used as an antimicrobial agent against a wide range of

\footnotetext{
*Correspondence: hjkim@kfri.re.kr

${ }^{1}$ Research Group of Consumer Safety, Korea Food Research Institute, Wanju, Jeollabuk-do 55365, Republic of Korea

Full list of author information is available at the end of the article
}

microorganisms causing wound infections [1]. A nitrous acid as a disinfectant for wastewater for $48 \mathrm{~h}$ treatment [4], and a hydrochloric acid ( $\mathrm{HCl})$ and organic acids composite was commercially used to spray on meat [5], and a $4 \log$ reduction in E. coli $\mathrm{O} 157: \mathrm{H} 7$ and Listeria monocytogenes abundance on the lettuce leaf combined with chlorinated water adjusted to $\mathrm{pH} 2.5$ [6] has a synergistic effect.

However, improper or sub-lethal application of acids can induce acid tolerance response (ATR), which contributes to the survival of infectious foodborne pathogens such as enterohaemorrhagic Escherichia coli (EHEC), Salmonella, Shigella spp., and Listeria monocytogenes in acidic environments, including the human 
gastrointestinal [2]. The risk of infection, including foodborne illness, may increase if the pathogen survives under extreme acid stress ( $\mathrm{pH} 2.0-3.0)$, as is found in the gastric fluid or following acid treatment of medical devices [7]. In our previous study, 22-33\% of commensal E. coli food isolates survived in gastric $\mathrm{pH}$ conditions of the Korean population, and thus the antimicrobial resistance gene can be transferred from the surviving cells to resident microbiota in the human gut [8]. However, ATR can cause many side-effects other than pathogen survival in acidic environments. For instance, that cross-protective properties can develop in acid-resistant cells is a typical example: ATR cells were reported to have increased resistance to several stresses including heat, salt, crystal violet, and antimicrobials [9]. ATR can also affect the ability of pathogens to bind to surfaces and form biofilms, by increasing cell-surface hydrophobicity, which correlates with pathogenic adhesion to various surfaces in medical and food environments [10,11].

These biological variabilities provide a mechanism for foodborne pathogens to survive in changing environmental conditions, and thus, are critical targets for mitigating the risk of infectious disease [12]. The relationship between differential gene expression and phenotypic variability, which is often determined by various omics technology, including genome-wide sequencing and transcript analysis, provides increasingly detailed insights into cellular responses to changing environments [13]. Moreover, analysis of transcriptome changes during the adaptation of foodborne pathogens following exposure to acidic environments can provide useful information for developing management strategies to reduce the risk of infectious diseases. Although ATR of foodborne pathogens is an important issue for public health, studies on gene expression profiles and cross-protection from antimicrobials in the context of ATR of foodborne pathogens are limited.

EHEC strains can cause a spectrum of human diseases, ranging from watery diarrhoea and bloody stool to serious extraintestinal complications such as haemolytic uremic syndrome. Among the two identified strains harbouring the Shiga toxin-producing gene, a clinical isolate of ATCC 43889 was selected herein, for analysing the transcriptome changes during ATR, as this isolate was originally acid-sensitive, however, was reported to adapt to acidic conditions [14-16]. In contrast, the well-known EDL933 (ATCC 43895) strain is already acid-resistant [2, $14,15]$. Considering the importance of ATR in foodborne pathogens for public health, analysis of the transcriptome and phenotypic changes during the adaptation of such pathogens to acidic environments can provide information that can be useful for developing intervention technologies and mitigating the risk owing to ATR pathogens.
Therefore, in the current study, we aimed to develop an acid-resistant ATCC 43889 strain via cell adaptation in a sub-lethal acidic environment for $100 \mathrm{~h}$. We conducted RNA sequencing (RNA-seq) and quantitative reverse transcription-polymerase chain reaction (qRT-PCR) to compare differentially expressed transcripts between the acid-adapted and non-adapted bacteria. We also performed de novo whole genome sequencing (WGS) of ATCC 43889, which has not been reported previously. Finally, antimicrobial resistance and biofilm formation of the ATR strains were investigated as changes in phenotypic characteristics related to cross-protection from antimicrobials of the ATR strain.

\section{Results}

\section{Acid adaptation of E. coli}

The $\mathrm{pH}$ change in $\mathrm{M} 9$ after $E$. coli inoculation was less than 0.02 from the original $\mathrm{pH}$ adjusted with $5 \mathrm{~N} \mathrm{HCl}$. During the $100 \mathrm{~h}$ incubation, no $\mathrm{pH}$ changes were observed in two independent experiments. Upon serially decreasing the $\mathrm{pH}$ from 4 , the lowest $\mathrm{pH}$ at which the acid-adapted ATCC 43889 was able to survive for $100 \mathrm{~h}$ was 2.75. The cells surviving at $\mathrm{pH} 2.75$ for $100 \mathrm{~h}$ were termed acid-adapted ATCC 43889. Figure 1 shows the fates of acid-adapted and non-adapted ATCC 43889 in M9 media of $\mathrm{pH} 2.75$ for $200 \mathrm{~h}$. The number of surviving acid-adapted cells was $3.58 \pm 0.30 \log \mathrm{CFU} / \mathrm{mL}$ at pH 2.75 for $100 \mathrm{~h}$. The acid-adapted cells survived even after $200 \mathrm{~h}$ incubation at $\mathrm{pH} 2.75$. However, the nonadapted cells did not survive for $100 \mathrm{~h}$ under the same $\mathrm{pH}$

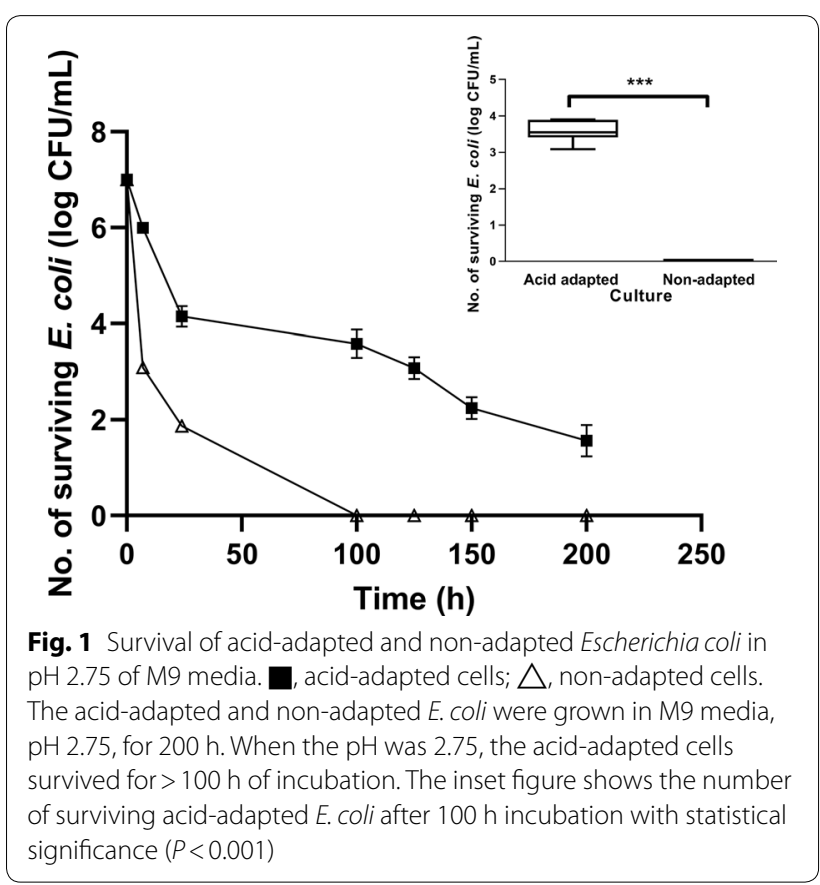


conditions. The number of cells surviving after $100 \mathrm{~h}$ of incubation at pH $2.75(\mathrm{p}<0.001)$ differed significantly for acid-adapted and non-adapted cells, which is shown in the inset of Fig. 1.

\section{General features of WGS}

Owing to a lack of available published WGS data for ATCC 43889, to map the RNA-seq data, we analysed the WGS of ATCC 43889. The detailed genomic sequences for ATCC 43889 are provided in Additional file 1: Tables $\mathrm{S} 1, \mathrm{~S} 2$, Figures S1 and S2. The analysed genome sequence of ATCC 43889 was determined to be 98 and $76 \%$ similar to that of EDL933 (acid-resistant pathogenic E. coli) and K-12 (commensal E. coli), respectively. The white gaps and area of low homology identified in intraspecies genome comparisons indicate $<50 \%$ identity with BLASTn matches. Moreover, ATCC 43889 contained unique regions at $5,400 \mathrm{~kb}$, with no matching genes reported for EDL933 or K-12 strains (Fig. 2). Within this region were 20 prophage-related unnamed genes, and 16 genes that encode hypothetical proteins, yegS, and hin.

\section{RNA-seq and differential expression analysis}

Total RNA was purified from the acid-adapted and nonadapted cells to identify the differentially expressed genes (DEGs). The RNA-seq results were mapped to those of WGS with ATCC 43889 as a reference strain (Additional file 1: Table S3). In total, 59 genes were differentially expressed between the acid-adapted and non-adapted strains. Twenty genes were upregulated and 49 were downregulated in the acid-adapted strain; the most differentially expressed genes are shown in Table 1, whereas the remainders are shown in Additional file 1: Table S4. The most highly upregulated named gene was $k d p A$, with a $\log _{2}$ 3.23-fold increase. The upregulated genes were associated with stress resistance and their expression levels were stress-induced; the $b h s A$ genes encode multiple stress resistance proteins, and two unnamed genes (RS06135 and RS08170) encode stress-induced bacterial acidophilic repeat motif protein. However, although the $\mathrm{p}$-value was $>0.05$, the polymyxin resistance gene $\operatorname{arn} A$ was also upregulated, suggesting that acid-adapted E. coli was cross-protected from the antimicrobial. The genes downregulated in this study mainly encoded a group of proteins associated with maltose metabolism such as lamB, malK, and malE.

\section{Validation of gene expression}

To validate the RNA-seq results, we performed qRT-PCR for six selected genes, $k d p A$, bsh $A, 6135,8170$, lamB, and malE, which showed significantly altered expression in RNA-seq (Table 1). The 16S rRNA housekeeping gene expression level did not differ for both acid adapted and non-adapted cells ( $\mathrm{Ct}$ value for acid-adapted cells were $5.35 \pm 0.73$ and non-adapted cells were $5.22 \pm 0.69$ ). The results of qRT-PCR are presented as means with standard deviations. A similar pattern of upregulation and downregulation was observed in both RNA-seq and qRT-PCR analyses (Fig. 3). However, the $\log _{2}$ fold-changes observed using qRT-PCR were slightly lower than those from RNA-seq. For example, the results of RNA-seq showed that $\operatorname{lamB}$ expression in acid-adapted cells was $\log _{2} 4.20$ fold lower than that in non-adapted cells, whereas this difference was only $\log _{2}-1.19 \pm 0.55$-fold in the qRTPCR results. Alternatively, for $k d p A$, qRT-PCR showed a higher fold-change in expression than did RNA-seq with the latter showing a $\log _{2} 3.10$-fold change, and qRT-PCR showed a $\log _{2} 3.69 \pm 2.44$-fold change. However, similar expression levels were observed for $b s h A \_3$ by RNA-seq $\left(\log _{2} 2.05\right.$-fold change) and qRT-PCR $\left(\log _{2} 1.64 \pm 0.48\right.$ fold change) analysis.

\section{Phenotype variation}

The lag phase duration of acid-adapted ATCC 43889 $8 \mathrm{~h}$ was (fourfold) longer than that of non-adapted cells $2 \mathrm{~h}$ with significance. The maximum population density of acid-adapted cells (OD 1.07) was lower than that of non-adapted cells (OD 1.31) ( $\mathrm{p}<0.01$, Fig. 4a), indicating the fitness cost of acid-adapted cells under normal conditions. Moreover, according to the results of the broth microdilution test, the minimal inhibitory concentration (MIC) of ATCC 43889 was 25,000 U/L for polymyxin B and $2 \mathrm{mg} / \mathrm{L}$ for colistin, suggesting that this strain has intermediate susceptibility [17]. However, no differences were observed between the MICs of acid-adapted and non-adapted cells (Fig. 4b, c). Further, no colonies were also observed at MIC according to the agar diffusion test of polymyxins. However, at sub-MIC, the acid-adapted $E$. coli showed higher resistance to polymyxin $\mathrm{B}$ and colistin than the non-adapted cells ( $<<0.01$, Fig. $4 \mathrm{~d}$, e), as indicated by upregulation of the polymyxin resistance gene. The induced resistance of acid-adapted cells to polymyxins suggests that acid adaptation provides cross-protection from other forms of environmental stress.

The initial number of inoculated bacterial cells in simulated gastric fluid (SGF) was approximately $5 \mathrm{log}$ $\mathrm{CFU} / \mathrm{mL}$. After the acid-adapted and non-adapted cells were exposed to the SGF for $3 \mathrm{~h}$, the number of acid-adapted cells (3.82 log CFU/mL) was $1 \log$ higher than that of non-adapted cells $(2.75 \log \mathrm{CFU} / \mathrm{mL})$ in the SGF ( $\mathrm{p}<0.001)$ (Fig. 4f).

Lastly, no significant changes were observed in biofilm formation during the first two days of incubation regardless of the presence of polymyxins. Furthermore, although the expression of $b h s A$, a gene related 


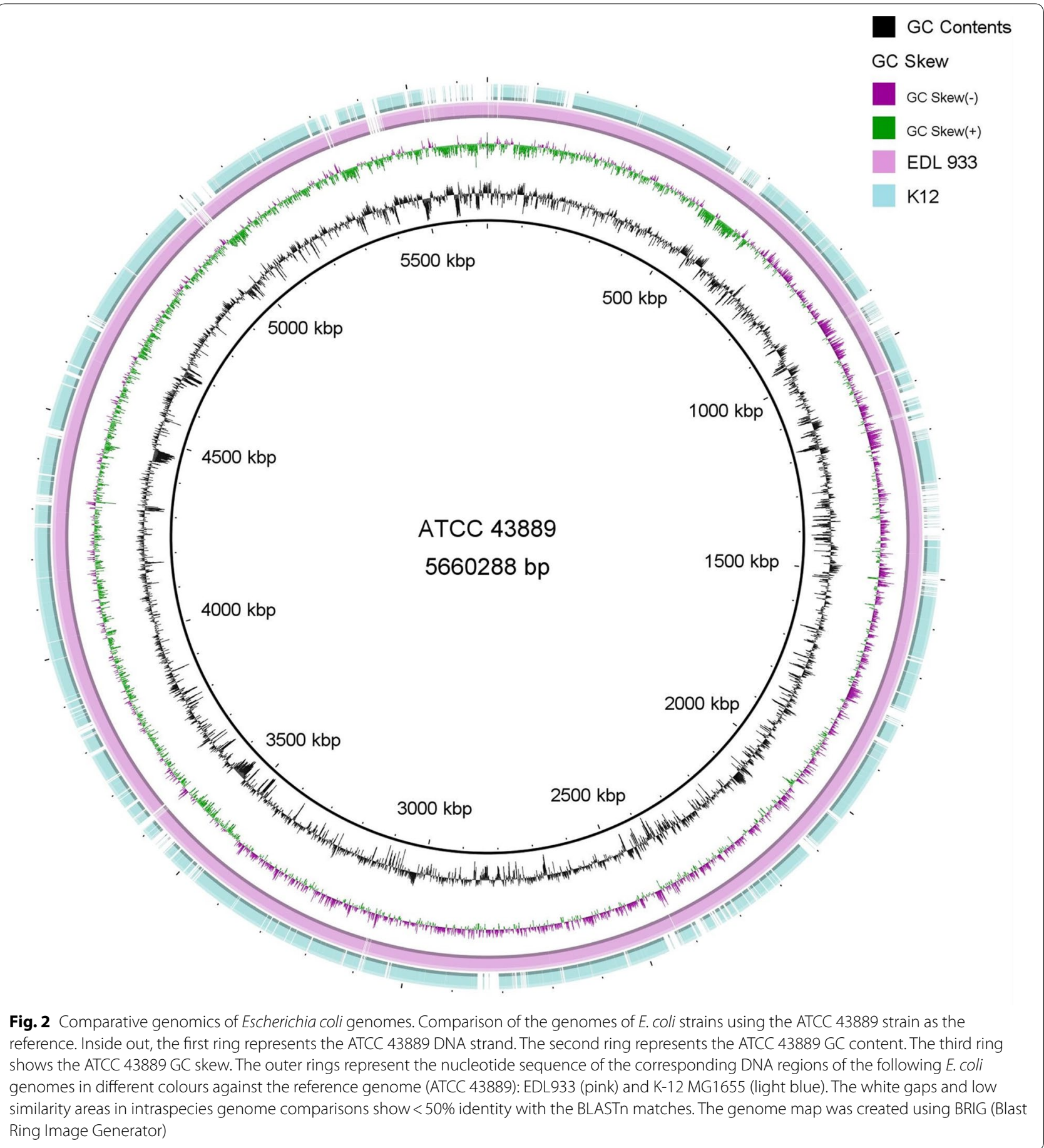

to biofilm formation, was upregulated in acid-adapted $E$. coli, during the seven days incubation without polymyxins, no significant changes were observed in biofilm formation. Alternatively, at sub-MIC concentrations, significantly higher biofilm formation were observed in acid-adapted cells following seven days of incubation, i.e., when cells were incubated at 6,250 and
$12,500 \mathrm{U} / \mathrm{L}$ of polymyxin $\mathrm{B}$ and 0.125 and $0.25 \mathrm{mg} / \mathrm{L}$ of colistin for seven days (Fig. 4g, h).

\section{Discussion}

Exposure of ATCC 43889 cells to acidic environments induces an acid adaptation response. A previous study showed that acid adaptation at approximately pH 5 was 
Table 1 Differentially expressed genes in acid-adapted E. coli 0157:H7 ATCC 43889 compared to corresponding nonadapted strains

\begin{tabular}{|c|c|c|c|c|c|c|c|}
\hline Regulation & Rank & length (bp) & $\begin{array}{l}\text { Fold } \\
\text { change } \\
\log _{2} \text { ratio }\end{array}$ & p-value & Gene symbol & Product & Functional category $^{a}$ \\
\hline \multirow[t]{30}{*}{ Up } & 1 & 189 & 4.95 & 0.02 & RS05560 & Cell division inhibition protein DicB & $\begin{array}{l}\text { Biological process: single-organism } \\
\text { process, cellular process, biological } \\
\text { regulation }\end{array}$ \\
\hline & 2 & 564 & 4.95 & 0.02 & RS06705 & Terminase small subunit & Biological process: cellular process \\
\hline & 3 & 207 & 3.72 & 0.08 & RS05320 & Phage tail protein & Cellular component: membrane, \\
\hline & 4 & 2124 & 3.72 & 0.08 & RS27375 & Terminase & Molecular function: binding \\
\hline & 5 & 366 & 3.61 & 0.02 & RS28370 & HNH endonuclease & Biological process: metabolic process \\
\hline & & & & & & & Molecular function: catalytic activity \\
\hline & 6 & 1674 & 3.23 & 0.01 & $k d p A$ & $\begin{array}{l}\text { Potassium-transporting ATPase A } \\
\text { chain }\end{array}$ & $\begin{array}{l}\text { Biological process: localization, organ- } \\
\text { ism process }\end{array}$ \\
\hline & & & & & & & $\begin{array}{l}\text { Cellular component: membrane part, } \\
\text { membrane, cell part }\end{array}$ \\
\hline & & & & & & & $\begin{array}{l}\text { Molecular function: transporter activ- } \\
\text { ity, binding, catalytic activity }\end{array}$ \\
\hline & 7 & 147 & 3.23 & 0.02 & RS06750 & Hypothetical protein & No hit \\
\hline & 8 & 261 & 2.63 & 0.03 & bhsA & $\begin{array}{l}\text { Multiple stress resistance protein } \\
\text { BhsA precursor }\end{array}$ & $\begin{array}{l}\text { Biological process: metabolic process, } \\
\text { single-organism process, cellular } \\
\text { process, response to stimulus }\end{array}$ \\
\hline & & & & & & & $\begin{array}{l}\text { Cellular component: membrane part, } \\
\text { cell part }\end{array}$ \\
\hline & 9 & 108 & 2.61 & 0.03 & RS08170 & Stress-induced bacterial acidophilic & Biological process: unclassified \\
\hline & & & & & & & Cellular component: unclassified \\
\hline & & & & & & & Molecular function: unclassified \\
\hline & 10 & 1491 & 2.54 & 0.03 & patA & Putrescine aminotransferase & $\begin{array}{l}\text { Biological process: metabolic process, } \\
\text { cellular process }\end{array}$ \\
\hline & & & & & & & Cellular component: cell part \\
\hline & & & & & & & $\begin{array}{l}\text { Molecular function: binding, catalytic } \\
\text { activity }\end{array}$ \\
\hline & 11 & 243 & 2.39 & 0.05 & RS16110 & $\begin{array}{l}\text { Polysaccharide production } \\
\text { threonine-rich protein }\end{array}$ & No hit \\
\hline & 12 & 468 & 2.27 & 0.08 & $R S 27360$ & Endopeptidase & Biological process: cellular process \\
\hline & 13 & 183 & 2.20 & 0.07 & RS06135 & Stress-induced bacterial acidophilic & Biological process: unclassified \\
\hline & & & & & & & Cellular component: unclassified \\
\hline & & & & & & & Molecular function: unclassified \\
\hline & 14 & 309 & 2.16 & 0.09 & RS04915 & Phage tail assembly protein $T$ & No hit \\
\hline & 15 & 141 & 2.15 & 0.08 & RS25935 & Hok/gef family protein & Cellular component: membrane \\
\hline & 16 & 430 & 2.15 & 0.08 & $i b p B$ & Small heat shock protein IbpB & $\begin{array}{l}\text { Biological process: response to } \\
\text { stimulus }\end{array}$ \\
\hline & & & & & & & Cellular component: cell part \\
\hline & & & & & & & Molecular function: binding \\
\hline & 17 & 96 & 2.09 & 0.09 & RSO3750 & Hypothetical protein & No hit \\
\hline & 18 & 132 & 2.07 & 0.11 & RS26305 & Hypothetical protein & No hit \\
\hline
\end{tabular}


Table 1 (continued)

\begin{tabular}{|c|c|c|c|c|c|c|c|}
\hline Regulation & Rank & length (bp) & $\begin{array}{l}\text { Fold } \\
\text { change } \\
\log _{2} \text { ratio }\end{array}$ & p-value & Gene symbol & Product & Functional category $^{a}$ \\
\hline & 19 & 1983 & 2.05 & 0.10 & $\operatorname{arnA}$ & $\begin{array}{l}\text { Bifunctional polymyxin resistance } \\
\text { protein ArnA }\end{array}$ & $\begin{array}{l}\text { Biological process: metabolic process, } \\
\text { response to stimulus, single-organ- } \\
\text { ism process, cellular process }\end{array}$ \\
\hline & & & & & & & $\begin{array}{l}\text { Molecular function: binding, catalytic } \\
\text { activity }\end{array}$ \\
\hline & 20 & 213 & 2.03 & 0.10 & RS00040 & Hypothetical protein & No hit \\
\hline \multirow[t]{23}{*}{ Down } & 1 & 222 & -6.75 & 0.01 & $R S 26915$ & $\begin{array}{l}\text { TraR/DksA family transcriptional } \\
\text { regulator }\end{array}$ & $\begin{array}{l}\text { Biological process: biological regula- } \\
\text { tion }\end{array}$ \\
\hline & 2 & 246 & -4.52 & 0.07 & RS27335 & Hypothetical protein & No hit \\
\hline & 3 & 366 & -4.21 & 0.01 & RS03415 & HNH endonuclease & Biological process: metabolic process \\
\hline & & & & & & & Molecular function: catalytic activity \\
\hline & 4 & 1341 & -4.20 & 0.00 & $\operatorname{lam} B$ & Maltoporin precursor & $\begin{array}{l}\text { Biological process: localization, } \\
\text { response to stimulus, multi- } \\
\text { organism process, single-organism } \\
\text { process, cellular process }\end{array}$ \\
\hline & & & & & & & $\begin{array}{l}\text { Cellular component: membrane } \\
\text { part, membrane, macromolecular } \\
\text { complex, cell part }\end{array}$ \\
\hline & & & & & & & $\begin{array}{l}\text { Molecular function: molecular trans- } \\
\text { ducer activity, transporter activity, } \\
\text { binding }\end{array}$ \\
\hline & 5 & 921 & -3.17 & 0.01 & malM & Maltose operon protein MalM & $\begin{array}{l}\text { Biological process: localization, } \\
\text { single-organism process }\end{array}$ \\
\hline & & & & & & & Cellular component: cell part \\
\hline & 6 & 750 & -3.03 & 0.01 & $\operatorname{invF}$ & Invasion protein InvF & $\begin{array}{l}\text { Biological process: biological regula- } \\
\text { tion }\end{array}$ \\
\hline & & & & & & & $\begin{array}{l}\text { Molecular function: nucleic acid bind- } \\
\text { ing transcription factor activity }\end{array}$ \\
\hline & 7 & 351 & -3.03 & 0.01 & RS15960 & Hypothetical protein & $\begin{array}{l}\text { Biological process: response to } \\
\text { stimulus }\end{array}$ \\
\hline & 8 & 228 & -2.92 & 0.07 & RS03410 & $\begin{array}{l}\text { DUF3950 domain-containing } \\
\text { protein }\end{array}$ & No hit \\
\hline & 9 & 285 & -2.92 & 0.02 & RS15965 & Hypothetical protein & No hit \\
\hline & 10 & 1116 & -2.81 & 0.02 & malk & $\begin{array}{l}\text { Maltose/maltodextrin import ATP- } \\
\text { binding protein MalK }\end{array}$ & $\begin{array}{l}\text { Biological process: localization, } \\
\text { single-organism process }\end{array}$ \\
\hline & & & & & & & $\begin{array}{l}\text { Cellular component: membrane } \\
\text { part, membrane, macromolecular } \\
\text { complex, cell part }\end{array}$ \\
\hline & & & & & & & $\begin{array}{l}\text { Molecular function: transporter } \\
\text { activity, }\end{array}$ \\
\hline & & & & & & & binding, catalytic activity \\
\hline & 11 & 333 & -2.79 & 0.02 & $R S 14560$ & DUF2686 family protein & No hit \\
\hline & 12 & 360 & -2.78 & 0.02 & $R S 15860$ & Hypothetical protein & No hit \\
\hline & 13 & 1191 & -2.72 & 0.02 & male & $\begin{array}{l}\text { Maltose-binding periplasmic pro- } \\
\text { tein precursor }\end{array}$ & $\begin{array}{l}\text { Biological Process: localization, } \\
\text { response to stimulus, single-organ- } \\
\text { ism process, - locomotion, cellular } \\
\text { process }\end{array}$ \\
\hline & & & & & & & $\begin{array}{l}\text { Cellular component: membrane part, } \\
\text { macromolecular complex, cell part }\end{array}$ \\
\hline & & & & & & & $\begin{array}{l}\text { Molecular function: transporter activ- } \\
\text { ity, binding }\end{array}$ \\
\hline
\end{tabular}


Table 1 (continued)

\begin{tabular}{|c|c|c|c|c|c|c|c|}
\hline Regulation & Rank & length (bp) & $\begin{array}{l}\text { Fold } \\
\text { change } \\
\log _{2} \text { ratio }\end{array}$ & p-value & Gene symbol & Product & Functional category ${ }^{a}$ \\
\hline & \multirow[t]{3}{*}{14} & \multirow[t]{3}{*}{1416} & \multirow[t]{3}{*}{-2.71} & \multirow[t]{3}{*}{0.02} & \multirow[t]{3}{*}{ thaA } & \multirow[t]{3}{*}{ Tryptophanase } & $\begin{array}{l}\text { Biological process: metabolic process, } \\
\text { single-organism process, cellular } \\
\text { process }\end{array}$ \\
\hline & & & & & & & $\begin{array}{l}\text { Cellular component: membrane, cell } \\
\text { part }\end{array}$ \\
\hline & & & & & & & $\begin{array}{l}\text { Molecular function: binding, catalytic } \\
\text { activity }\end{array}$ \\
\hline & \multirow[t]{3}{*}{15} & \multirow[t]{3}{*}{927} & \multirow[t]{3}{*}{-2.63} & \multirow[t]{3}{*}{0.03} & \multirow[t]{3}{*}{ COAA_1 } & \multirow[t]{3}{*}{ Pantothenate kinase } & $\begin{array}{l}\text { Biological process: metabolic process, } \\
\text { single-organism process, cellular } \\
\text { process }\end{array}$ \\
\hline & & & & & & & Cellular component: cell part \\
\hline & & & & & & & $\begin{array}{l}\text { Molecular function: binding, catalytic } \\
\text { activity }\end{array}$ \\
\hline
\end{tabular}

a Functional categories were based on $\mathrm{GO}$ analysis classifications were based on annotation from the $E$. coli best-hit gene models $\left(\mathrm{E}\right.$ value $\left.\leq 10^{-5}\right)$ and $\mathrm{GO}$ analysis search using the BLAST2GO program

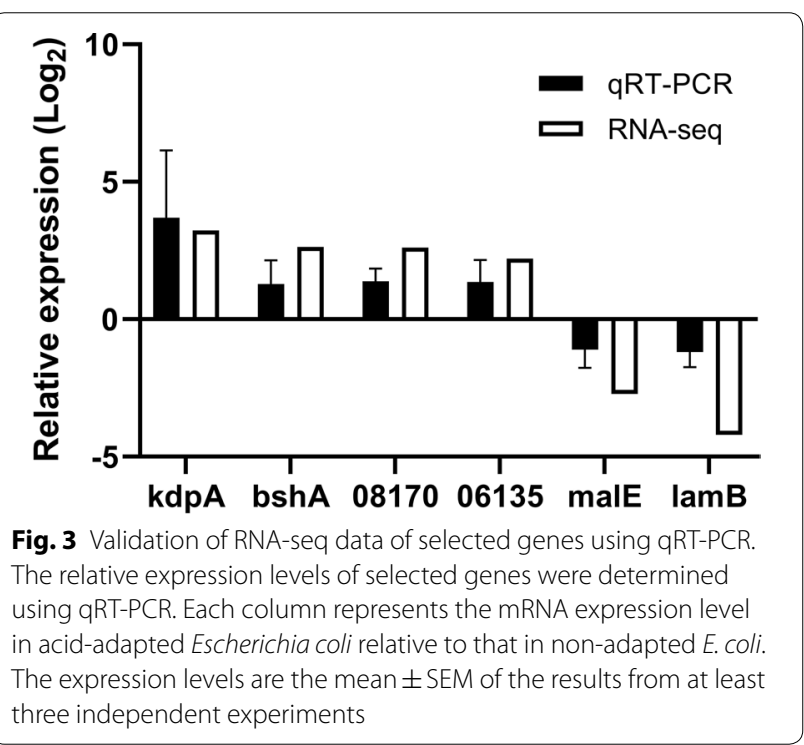

required to obtain increased resistance to a sub-lethal $\mathrm{pH}$ ( $\mathrm{pH}$ 3.0) [14, 18]. Furthermore, acid adaptation may result in enhanced protection against lethal heat, a process often referred to as cross-protection owing to exposure of bacteria to acidic conditions. However, information regarding transcriptomic changes in ATCC 43889 adapted under sub-lethal pH conditions is limited. In this study, transcriptomic changes were observed in $E$. coli adapted at the extremely acidic $\mathrm{pH}$ of 2.75 , which is found in some food items such as vinegar [19]. As the gastric $\mathrm{pH}$ in humans ranges from 2.0 to 4.8 depending on the food buffering capacity [20], E. coli adapted to $\mathrm{pH}$ 2.75 can survive in the human stomach, the first barrier against pathogens that cause foodborne illness, or transfer virulence genes, as well as antimicrobial resistance genes, to gut microbiota or to bacteria in the external environment such as food and/or biofilms [8, 21, 22].

As predicted, the RNA-seq results showed that genes associated with stress regulation were upregulated in acid-adapted cells. In our study, $k d p A$ was highly upregulated $\left(\log _{2} 3.23\right.$-fold) in the acid-adapted cells, compared to that in the non-adapted cells, thus supporting the results of a previous study [23]. $k d p A$ encodes a potassium-binding subunit of a potassium-transporting ATPase, which functions to bind and transport potassium ions across the cytoplasmic membrane [24]. Responses to acidic stress involve different cellular mechanisms, such as proton pumps [25]. Martirosov et al. described the $\mathrm{H}^{+}-\mathrm{K}^{+}$exchanging system, which involves a dicyclohexylcarbodiimide-sensitive exchange of $2 \mathrm{H}^{+}$from cells for $1 \mathrm{~K}^{+}$, and it is carried out through a proton pump [26]. Furthermore, the KdpFABC complex comprises an ion channel, an ion pump, and an $\mathrm{ABC}$ transporter. The KdpA protein corresponds structurally to an ion channel [27]. This is essential for the survival of E. coli as it blocks $\mathrm{H}^{+}$ions from crossing the cell membrane. Moreover, upregulated $k d p A$ was detected in acid-adapted Salmonella Typhimurium [28]. In this study, $k d p A$ was upregulated in $E$. coli that survived in acidic environments for more than $100 \mathrm{~h}$. Additionally, upregulation of bhsA (previously $y c f R$ ), which encodes a putative outer membrane protein, was also observed. During chlorine treatment, $b h s A$ was the most significantly upregulated gene, which encodes a protein directly involved in the cellular transport of metabolites $[29,30]$. bhsA is also known to significantly induce biofilm formation in E. coli, although no 

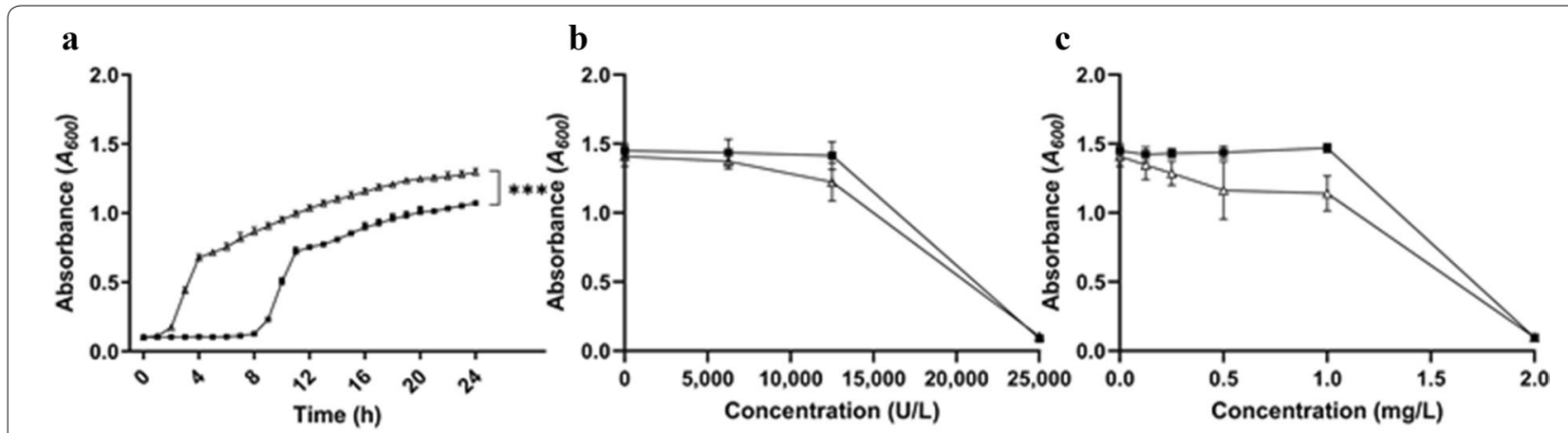

d

e

\section{f}
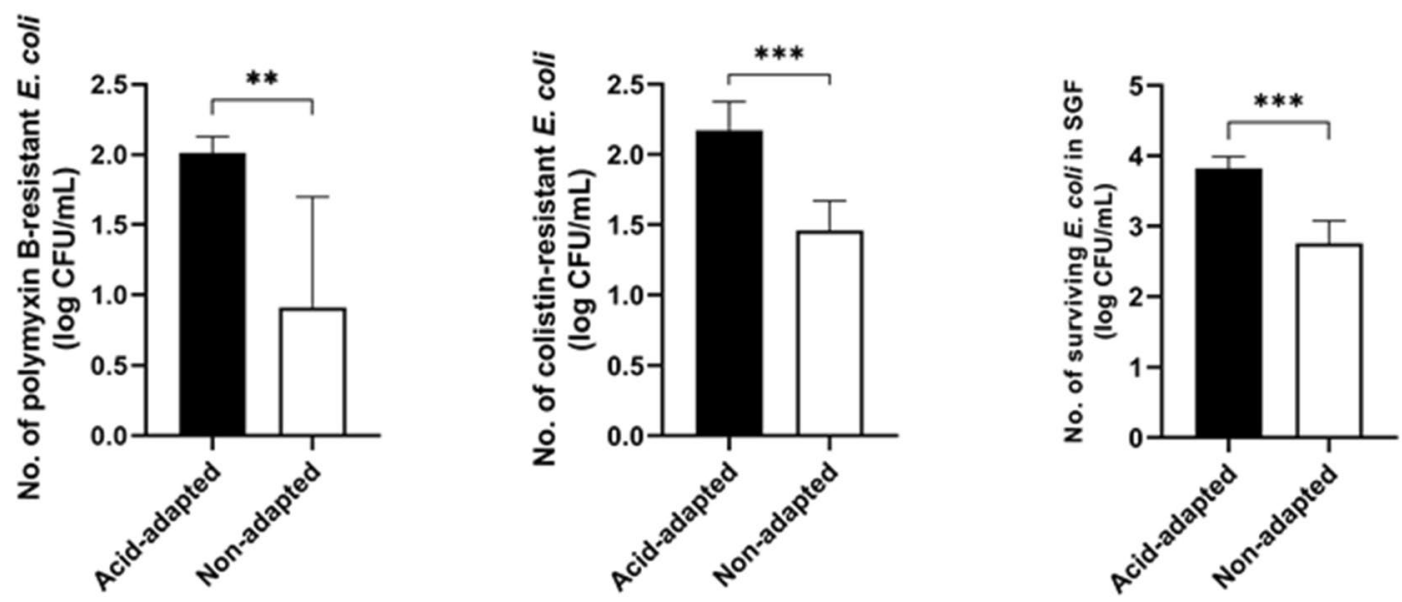

g

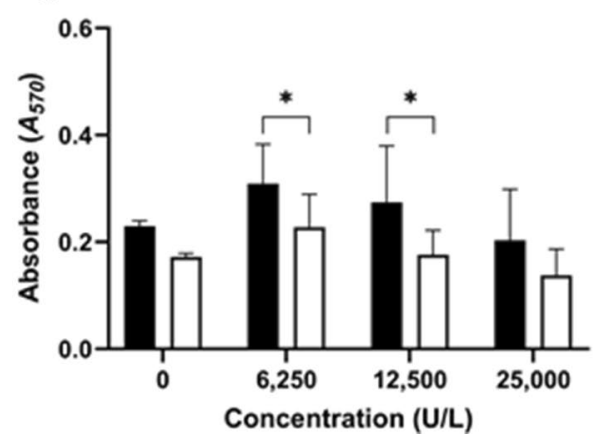

$\mathbf{h}$

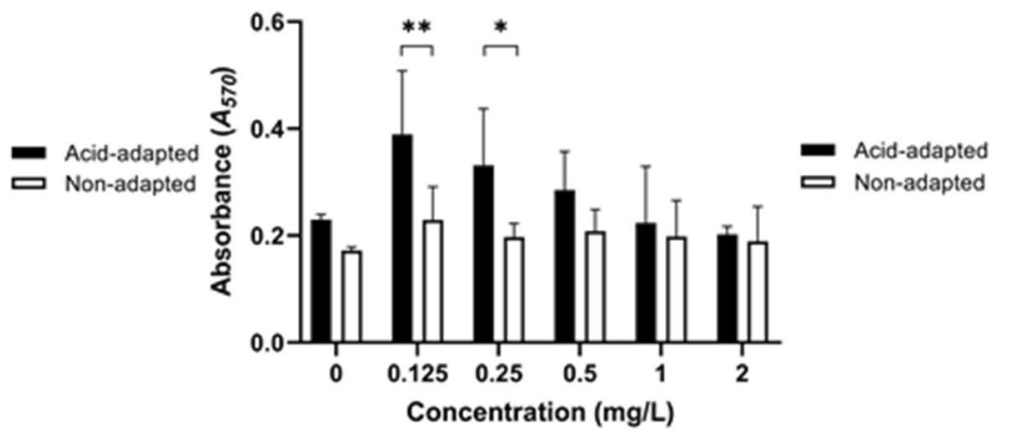

Fig. 4 Growth rate, antimicrobial resistance, and biofilm formation of acid-adapted and non-adapted cells. $p<0.05(*), 0.01(* *)$, and $0.001(* * *)$. a The absorbance of acid-adapted cells was fourfold higher at the lag phase than that of the non-adapted cells in tryptic soy broth. The maximum population density of acid-adapted cells was lower than that of non-adapted cells $(p<0.001) \mathbf{\square}$, acid-adapted cells; $\triangle$, non-adapted cells. $\mathbf{b}$ MIC of polymyxin B for ATCC 43889. acid-adapted cells; $\triangle$, non-adapted cells. c MIC of colistin for ATCC 43889 . acid-adapted cells; $\triangle$, non-adapted cells. d Survival of Escherichia coli on MHA with polymyxin B (12,500 U/L). The number of polymyxin B-resistant acid-adapted cells was higher than that of non-adapted cells $(p<0.01)$. e Survival of E. coli on MHA with colistin $(1 \mathrm{mg} / \mathrm{L})$. The number of colistin-resistant acid-adapted cells was higher than that of non-adapted cells $(p<0.001)$. f Survival of $E$. coli in simulated gastric fluid for $3 \mathrm{~h}$. The number of surviving acid-adapted cells were 1 log higher than that of non-adapted cells $(p<0.001)$. $\mathbf{g}$ Biofilm formation of cells incubated with polymyxin B. $\mathbf{h}$ Biofilm formation of cells incubated with colistin

significant increase in biofilm formation was observed in the acid-adapted cells in this study.

The growth rate of the acid-adapted cells was lower than that of non-adapted cells under the same conditions, which may result from fitness cost as resistance to environmental changes is often related to reduced bacterial fitness (the ability to survive and reproduce) [31]. Alternatively, reduced growth rate of the acid-adapted 
cells may be related to downregulation of $\operatorname{lamB}$, malK, and $m a l E$, which are associated with maltose metabolism. According to Nuoffer et al., E. coli produces glucose intracellularly via phosphorylation of maltose [32]. A previous report showed that the genes regulating maltose metabolism (malE, lamB) were highly upregulated when glucose was limited as a nutrient [33]. We observed a decrease in the expression of maltose genes in acid-adapted cells, which is supported by the results of a previous study which reported that expression of lamb, encoding the maltoporin precursor, was strongly reduced in various $\mathrm{K}-12$ strains, as observed using SDS-PAGE, when the $\mathrm{pH}$ of the growth medium was decreased [34]. Moreover, the expression of malE, a gene associated with maltose-binding periplasmic protein maltose receptor, decreased during recovery from acid stress [35]. malE is known to be related to alkaline induction [36]. Therefore, downregulation of $\operatorname{lamB}$ and malE may be a hallmark of acid adaptation.

Interestingly, $\operatorname{gad} A / B$ was not identified in our differential gene expression analysis, which may have been caused by two factors. First, M9 media does not contain glutamate. Previous studies have shown that the glutamate-dependent AR pathway consists of the glutamate decarboxylases $\operatorname{gad} A / B$ and the glutamate $/ \gamma$ aminobutyric acid antiporter $\operatorname{gad} C$, which showed low activity in the absence of glutamate [37]. Second, $\operatorname{gad} A / B$ undergoes a stepwise conformational change to its inactive form when the $\mathrm{pH}$ increases back to neutral, and the optimal $\mathrm{pH}$ for gadABCEWX and $y b a S$ gene expression is $\mathrm{pH} 5.5$ [38-41]. Gene expression patterns differ following long- and short-term acid adaptation; for example, gene expression of E. coli $\mathrm{K}-12$ in glucose-limited media after short-term adaptation was 12.6-fold higher than that after long-term adaptation [42]. These results suggest that gene expression is reduced after long-term adaptation.

Interestingly, in this study, the polymyxin resistance gene $\operatorname{arn} A$ was upregulated in acid-adapted $E$. coli O157:H7, and the antimicrobial resistance against polymyxin B and colistin confirmed the phenotypic changes in these cells. There is similar report on the development of antimicrobial resistance in the foodborne pathogens (E. coli, S. Typhimurium, and S. aureus) exposed to acidic conditions, i.e., resistance against amikacin, ceftriaxone and trimethoprim for gram negative strains and gentamicin and erythromycin for gram positive strains were developed when the cells are contact with sublethal $\mathrm{pH}$ conditions for $24 \mathrm{~h}$ [43]. However, the upregulated arnA did not affect the MIC of polymyxins in acid-adapted cells. According to Sinel et al., a 14.3-fold upregulation of the gene encoding the quinolone resistant protein resulted in a 2- to 6-fold increase in MIC for
Enterococcus faecium [44]. Owing to the prevalence of antibiotic resistance and lack of novel classes of antibiotics in the development pipeline, clinical use of polymyxins has significantly increased over the past decades [45]. The most common mechanism of acquired resistance to polymyxins is modification of the bacterial outer membrane lipopolysaccharide. Global epidemiological surveillance studies have reported the occurrence of polymyxin resistance to be common in Enterobacteriaceae, specifically in Enterobacter species and in Acinetobacter baumannii [46]. Considering the limited number of agents available for treating infections caused by multidrugresistant gram-negative organisms [46], the emergence of polymyxin resistance, particularly from the cross-protection of acid-adapted EHEC, is of considerable concern. In this study, increased biofilm formation was observed at sub-MIC concentrations of polymyxins, which provides additional protection against environmental stresses including antimicrobials. Similar results on increased biofilm formation in E. coli were observed under subMIC concentrations of glycopeptide, cyclic peptide, fluoroquinolone, and $\beta$-lactam [47].

This study has some limitations; acid adaptation procedure was not a typical, but considering practices in the food industries or medical environments. It is more realistic to alternate exposure to acidic and neutral environments. We only observed phenotypic changes and DEG of acid-adapted E. coli $\mathrm{O} 157: \mathrm{H} 7$ but molecular basis was not explored. Thus, studies on the phenotypic changes and DEGs of other types of pathogenic E. coli and molecular basis (e.g. gene deletion and/or protein study) of the acid-adapted cells are needed in the future work. However, phenotypic changes in ATR of pathogenic bacteria with relation to gene expression can be incorporated in safety management of infectious pathogens to ensure public health.

\section{Conclusion}

In this study, the ATCC 43889 strain, which was originally acid-sensitive, was adapted under sub-lethal acidic conditions. WGS showed that the genetic sequence was 98\% homologous to that of the EDL933 strain, which is an acid-resistant strain. The main findings of the study are as follows; (i) upregulation of the antimicrobial resistance gene $\operatorname{arn} A$ in the acid-adapted ATCC 43889 strain, which was validated, induced antimicrobial resistance against polymyxin $\mathrm{B}$ and colistin; (ii) upregulation of stress-related genes, including $k d p \mathrm{~A}$ and $b s h \mathrm{~A}$; and (iii) survival of acid-adapted cells in SGF was higher than that of non-adapted cells. The results of genomic, transcriptomic, and phenotypic analyses of the acid-adapted cells have provided information that will be useful for developing safety management strategies to reduce the risk of 
infectious diseases and for further studies on the antibiotic resistance of acid-adapted pathogens.

\section{Materials and methods}

\section{Preparation of bacterial strain and acid adaptation}

The E. coli O157:H7 (Migula) Castellani and Chalmers ATCC $^{\circledR} 43889^{\text {TM }}$ strain was obtained from the National Culture Collection for Pathogens (Osong, Korea). The commensal E. coli ATCC ${ }^{\circledR} 10536^{\mathrm{TM}}$, obtained from the Korean Type Culture Collection (Daejeon, Korea), was used as negative control. Bacteria were inoculated into $5 \mathrm{~mL}$ of tryptic soy broth (TSB) (Merck, Darmstadt, Germany) in $17 \times 100$-mm glass culture tubes at $37{ }^{\circ} \mathrm{C}$ for $24 \mathrm{~h}$ in a shaking incubator at $140 \mathrm{rpm}$ (SI-600R, Jeio Tech, Korea). A volume of $50 \mu \mathrm{L}$ of the broth cultures of a stationary phase was subsequently transferred to $5 \mathrm{~mL}$ of M9 minimal media containing $0.4 \%$ glucose supplemented (MB Cell, Los Angeles, CA, USA) at $37{ }^{\circ} \mathrm{C}$ for $24 \mathrm{~h}$ with agitation. The cells were harvested, washed, and suspended in phosphate buffered saline (PBS) (Gibco, Rockville, MD) to obtain a stationary phase-adjusted concentration of approximately $10^{7} \mathrm{CFU} / \mathrm{mL}$. For the acid-adapted ATCC 43889 strain, a $200-\mu \mathrm{L}$ aliquot of the cultures was transferred to $10 \mathrm{~mL}$ M9 media without supplement at $\mathrm{pH}$ 4. The $\mathrm{pH}$ of $\mathrm{M} 9$ (control, $\mathrm{pH}$ 7.4) was adjusted by adding $5 \mathrm{~N}$ hydrochloric acid (Kanto Chemical, Tokyo, Japan; PubChem CID: 313) before inoculation. Next, the inoculated acidic M9 was incubated for 24, 50,75 , and $100 \mathrm{~h}$ with agitation without medium change. After incubation, the cultures were serially diluted and the adapted cells were recovered in triplicate on Luria Bertani agar (LB) (Merck) and sorbitol-MacConkey agar (SMAC) (Merck) at $37{ }^{\circ} \mathrm{C}$ for $24 \mathrm{~h}$. Following $100 \mathrm{~h}$ of incubation in acidic growth media, the surviving bacteria were recovered after incubation on agar plates for $24 \mathrm{~h}$ and the colonies were counted. If colonies were recovered on both agar plates, a single colony was picked from SMAC agar and the process was repeated in $\mathrm{pH}$ reduced by 0.25 until no colonies were recovered. The $\mathrm{pH}$ of $\mathrm{M} 9$ media immediately preceding the $\mathrm{pH}$ at which no colonies were obtained was considered the final acid-adapted $\mathrm{pH}$. At the final $\mathrm{pH}$, a $200-\mu \mathrm{L}$ aliquot of acid-adapted and non-adapted cells were transferred to $10 \mathrm{~mL}$ of acidic M9 media without supplement and incubated for $200 \mathrm{~h}$ with agitation without medium change to analyse survival as presented in Fig. 1. Survival of E. coli in acidic M9 media were performed in duplicate and the data presented were obtained from at least three independent experiments.

\section{DNA isolation, WGS, assembly, and functional annotation}

The experimental procedures are described in detail in the Additional file 1.

\section{Total RNA isolation and RNA-seq}

RNA-seq analysis was used to compare gene expression between acid-adapted and non-adapted cells. Total RNAs were isolated from acid-adapted cells that survived at $\mathrm{pH} 2.75$ of $\mathrm{M} 9$ medium for $150 \mathrm{~h}$ and the corresponding non-adapted cells using a Qiazol lysis reagent (Qiagen $\mathrm{GmbH}$, Hilden, Germany) according to the manufacturer's instructions. The DNA in each sample was removed using an on-column digestion using RNase-free DNase I (Qiagen).

Following RNA extraction and DNase I treatment, ribosomal RNA (rRNA) was removed using the RiboZero rRNA removal kit (Bacteria) (Illumina, San Diego, CA, USA) and cDNA was synthesised using DNA polymerase I and RNase $\mathrm{H}$ (Illumina) according to the manufacturer's instructions. The quantity and quality of the total RNA was analysed using NanoVue Plus (GE Healthcare, Buckinghamshire, UK) and a 2100 Bioanalyzer (Agilent Technologies, Santa Clara, CA, USA) with an RNA integrity number $(\mathrm{RIN}) \geq 8$. The purified expression libraries were sequenced $(100$ base pair $(b p) \times 2)$ using a HiSeq 2000 (Illumina) platform. The presented RNAsequencing data were obtained from an independent experiment and analysed in duplicate.

\section{Quality control and data analysis of RNA-seq}

Sequence read data were analysed with FastQC (v0.10), which provides a modular set of analyses and can rapidly reveal sequence quality [48]. In addition, Trimmomatic (v0.32) was used to trim and crop Illumina (FASTQ) data and remove adapters [49], whereas Bowtie was used to align sequences [50]. DEGs were analysed using edgeR and the $\mathrm{p}$-value was obtained from total count normalisation [51].

An in-house script was used to calculate the reads per kilobase per million (RPKM) for individual transcripts [52]. At least one sample with an RPKM value of zero was excluded from the analysis. The quintile method of normalisation was then applied to reduce systematic bias [53]. Genes with differential expression indicated by an absolute $\log _{2}$ (fold change) $\geq 2$ were selected.

\section{qRT-PCR validation}

qRT-PCR was performed to confirm the DEGs identified using RNA-seq. The primer sequences of candidate genes/transcripts and a housekeeping gene (16S rRNA) were designed using NCBI Primer BLAST (Additional file 1: Table S5). cDNA was synthesised using the Maxima first strand cDNA synthesis kit for qRT-PCR (Thermo Scientific, Waltham, MA, USA) according to the manufacturer's instructions. SYBR Green (Thermo Scientific) PCR $(20 \mu \mathrm{L})$ was performed in duplicate for each sample using $250 \mathrm{ng}$ cDNA and $300 \mathrm{nM}$ each of the forward and reverse primers. Forty cycles of 
amplification and data acquisition were performed on a PikoReal 96 real-time PCR system (Thermo Scientific) (Additional file 1: Table S5). The $2^{-\Delta \Delta \mathrm{Ct}}$ method was used to evaluate the expression levels of each target gene compared to that of the $16 \mathrm{~S}$ rRNA internal control [54]. All experiments were performed in duplicate and the data presented were obtained from at least three independent experiments.

\section{Phenotyping for growth rate and antimicrobial resistance}

Strains that show differential expression of genes under different conditions may show phenotypic variations. To compare growth rate, the acid-adapted and non-adapted cells were incubated in $5 \mathrm{~mL}$ TSB at $37^{\circ} \mathrm{C}$ for $24 \mathrm{~h}$ with agitation, and the absorbance of the broth cultures was evaluated using a BioTek synergy Mx (BioTek Instruments, Winooski, VT, USA) at $600 \mathrm{~nm}$.

To determine the antimicrobial resistance of acidadapted and non-adapted cells, the MIC of polymyxins was determined by broth microdilution according to a previous study and recommendation of the joint CLSI-EUCAST polymyxin breakpoints, cation-adjusted Mueller-Hinton Broth (Merck) using concentrations of 400,000 U/L polymyxin B sulfate salt (Sigma; PubChem CID: 9833652) and $8 \mathrm{mg} / \mathrm{L}$ colistin sulfate salt (Sigma; PubChem CID: 73090) and serially diluted without surfactants (i.e. polysorbate-80) $[55,56]$. Polymyxin agar test was also performed [17]. Muller Hinton agar (MHA) plates were prepared with $12,500 \mathrm{U} / \mathrm{L}$ polymyxin B sulfate salt and $1 \mathrm{mg} / \mathrm{L}$ colistin sulfate salt, which were then inoculated with $100 \mu \mathrm{L}$ of $0.5 \mathrm{McF}$ arland suspension and incubated for $20 \mathrm{~h}$ at $37{ }^{\circ} \mathrm{C}$. Plates with visible growth of microorganisms was read as positive.

Survival of acid-adapted and non-adapted cells in SGF with pH adjusted to 2.75 was determined. A $100 \mu \mathrm{L}$ bacterial suspension was inoculated into $10 \mathrm{~mL}$ of SGF prepared as previously described [57]. The culture was incubated at $37^{\circ} \mathrm{C}$ with agitation for $180 \mathrm{~min}$, then 100 $\mu \mathrm{L}$ of the bacterial suspension was plated in triplicate onto SMAC.

Biofilms were formed in the presence of polymyxin $\mathrm{B}$ $(0,6250,12,500$, and 25,000 U/L) and colistin $(0,0.125$, $0.25,0.5,1.0$, and $2.0 \mathrm{mg} / \mathrm{L}$ ) for 1,2 , and 7 days using the procedure developed by Zhu and Mekalanos [58].

All the above experiments were performed in duplicate and the data presented were obtained from at least three independent experiments.

\section{Statistical analyses of experimental data}

The generated data were analysed for statistical significance using the paired two-tailed Student's $t$-test of GraphPad Prism 8 (GraphPad Software, Inc., San Diego, CA). P values $<0.05$ were considered statistically significant.

\section{Supplementary information}

Supplementary information accompanies this paper at https://doi. org/10.1186/s13099-020-00390-5.

Additional file 1: Table S1. Genomic features of ATCC 43889. Table S2. Pfam analysis on whole genome annotation. Table S3. Statistics of RNAseq alignment of acid-adapted cells and non-adapted cells when mapped to the reference genome. Table S4. Differentially expressed genes downregulated in acid-adapted E. coli O157:H7 ATCC 43889 compared to corresponding non-adapted using RNA sequencing after rank 16. Table S5. Primer sequences for qRT-PCR. Figure S1. Subsystem distribution of SEED and Kyoto Encyclopaedia of Genes and Genomes (KEGG). (A) Distribution of genes assigned to 600 SEED subsystems (based on the RAST annotation server). (B) In total, 698 genes were assigned to KEGG distribution (based on BLAST KOALA annotation server). Figure S2. Gene Ontology (GO) classification of the 5327 annotated proteins. GO analysis classifications were based on annotation from the $E$. coli best-hit gene models ( $E$ value $\leq 10^{-5}$ ) and $\mathrm{GO}$ analysis search using the BLAST2GO programme.

\section{Authors' contributions}

HJK designed, organised, and supervised the experiments, interpreted the results, and edited and revised the manuscript. SMK interpreted the results and edited the manuscript. DH performed laboratory experiments and drafted and revised the manuscript. All authors read and approved the final manuscript.

\section{Funding}

This work was supported by the Korea Food Research Institute under Grant [E0192101-02].

\section{Data availability}

The WGS project of E. coli O157:H7 ATCC 43889 has been deposited in GenBank under the accession number CP015853-4.

\section{Ethics approval and consent to participate}

Not applicable.

\section{Consent for publication}

Not applicable.

\section{Competing interests}

Not applicable.

\section{Author details \\ ${ }^{1}$ Research Group of Consumer Safety, Korea Food Research Institute, Wanju, Jeollabuk-do 55365, Republic of Korea. ${ }^{2}$ Department of Food Biotech- nology, University of Science and Technology, Daejeon 34113, Republic of Korea. ${ }^{3}$ Department of Human Ecology, Korea National Open University, Seoul 03087, Republic of Korea.}

Received: 29 July 2020 Accepted: 18 October 2020 Published online: 01 December 2020

References

1. Wang L, Bassiri M, Najafi R, Najafi K, Yang J, Khosrovi B, et al. Hypochlorous acid as a potential wound care agent: part I. Stabilized hypochlorous acid: a component of the inorganic armamentarium of innate immunity. J Burns Wounds. 2007;6:e5.

2. Foster JW. Escherichia coli acid resistance: tales of an amateur acidophile. Nat Rev Microbiol. 2004;2:898-907. 
3. Foster JW, Hall HK. Adaptive acidification tolerance response of Salmonella typhimurium. J Bacteriol. 1990;172(2):771-8.

4. Pijuan $M$, Wang $Q$, Ye L, Yuan Z. Improving secondary sludge biodegradability using free nitrous acid treatment. Bioresour Technol. 2012;1 16:92-8.

5. Wheeler TL, Kalchayanand N, Bosilevac JM. Pre- and post-harvest interventions to reduce pathogen contamination in the U.S. beef industry. Meat Sci. 2014;98(3):372-82

6. Park C-M, Hung Y-C, Doyle MP, Ezeike GOI, Kim C. Pathogen reduction and quality of lettuce treated with electrolyzed oxidizing and acidified chlorinated water. J Food Sci. 2001;66(9):1368-72.

7. Kanjee U, Houry WA. Mechanisms of acid resistance in Escherichia coli. Annu Rev Microbiol. 2013;67(1):65-81.

8. Hwang D, Kim SM, Kim HJ. Modelling of tetracycline resistance gene transfer by commensal Escherichia coli food isolates that survived in gastric fluid conditions. Int J Antimicrob Agents. 2017;49(1):81-7.

9. Leyer GJ, Johnson EA. Acid adaptation induces cross-protection against environmental stresses in Salmonella typhimurium. Appl Environ Microbiol. 1993;59(6):1842-7.

10 Yousef AE, Juneja VK. Microbial stress adaptation and food safety. Boca Raton: CRC Press; 2002.

11. Li Y-H, Hanna MN, Svensäter G, Ellen RP, Cvitkovitch DG. Cell density modulates acid adaptation in Streptococcus mutans: implications for survival in biofilms. J Bacteriol. 2001;183(23):6875-84.

12. Delignette-Muller ML, Rosso L. Biological variability and exposure assessment. 2000;58:203-12.

13 Zhang W, Li F, Nie L. Integrating multiple 'omics' analysis for microbial biology : application and methodologies. Microbiology. 2010;156:287-301.

14. Cheng H-Y, Yu R-C, Chou C-C. Increased acid tolerance of Escherichia coli O157: H7 as affected by acid adaptation time and conditions of acid challenge. Food Res Int. 2003;36(1):49-56.

15. Berry ED, Cutter CN. Effects of acid adaptation of Escherichia coli O157:H7 on efficacy of acetic acid spray washes to decontaminate beef carcass tissue. Appl Environ Microbiol. 2000;66(4):1493-8.

16. Reischl U, Youssef MT, Kilwinski J, Lehn N, Zhang WL, Karch H, et al. Realtime fluorescence PCR assays for detection and characterization of Shiga toxin, intimin, and enterohemolysin genes from Shiga toxin-producing Escherichia coli. J Clin Microbiol. 2002;40(7):2555-65.

17. Melanie T. Mahoney, Hirsch EB. What's new from the CLSI subcommittee on antimicrobial susceptibility testing. https://www.contagionlive.com. 2019. https://www.contagionlive.com/publications/contagion/2019/ october/whats-new-from-the-clsi-subcommittee-on-antimicrobial-susce ptibility-testing

18. Buchanan RL, Edelson SG. Culturing enterohemorrhagic Escherichia coli in the presence and absence of glucose as a simple means of evaluating the acid tolerance of stationary-phase cells. Appl Environ Microbiol. 1996;62(11):4009-13.

19. Lalou S, Hatzidimitriou E, Papadopoulou M, Kontogianni VG, Tsiafoulis CG, Gerothanassis IP, et al. Beyond traditional balsamic vinegar: compositional and sensorial characteristics of industrial balsamic vinegars and regulatory requirements. J Food Compos Anal. 2015;43:175-84.

20. Simonian HP, Vo L, Doma S, Fisher RS. Regional postprandial differences in $\mathrm{pH}$ within the stomach and gastroesophageal junction. Dig Dis Sci. 2005;50(12):2276-85.

21. Huddleston JR. Horizontal gene transfer in the human gastrointestinal tract: potential spread of antibiotic resistance genes. Infect Drug Resist. 2014;20(7):167-76.

22. Rossi F, Rizzotti L, Felis GE, Torriani S. Horizontal gene transfer among microorganisms in food: current knowledge and future perspectives. Food Microbiol. 2014;42:232-43.

23. Peng S, Stephan R, Hummerjohann J, Tasara T. Transcriptional analysis of different stress response genes in Escherichia coli strains subjected to sodium chloride and lactic acid stress. FEMS Microbiol Lett. 2014;361 (2):131-7.

24. Maiden MCJ, Jones-Mortimer MC, Harnett JE, Holman GI, Munday KA, Feany $\mathrm{MH}$, et al. Multiple mechanisms, roles and controls of $\mathrm{K}$ transport in Escherichia coli. Eur J Hiochem. 1993;215:54.

25 Shabayek S, Spellerberg B. Acid stress response mechanisms of group B Streptococci. Front Cell Infect Microbiol. 2017;7:395.

26 Martirosov SM, Petrosian LS, Trchounian AA, Vartanian AG. An electrochemical study of energy-dependent potassium accumulation in E. coli: membrane potential (in comparison with that of S. faecalis). J Electroanal Chem Interfacial Electrochem. 1981;128:613-20.

27. Greie J-C. The KdpFABC complex from Escherichia coli: a chimeric K+ transporter merging ion pumps with ion channels. Eur J Cell Biol. 2011;90(9):705-10.

28. Ryan D, Pati NB, Ojha UK, Padhi C, Ray S, Jaiswal S, et al. Global transcriptome and mutagenic analyses of the acid tolerance response of Salmonella enterica serovar typhimurium. Appl Environ Microbiol. 2015:81(23):8054-65.

29. Wang S, Deng K, Zaremba S, Deng X, Lin C, Wang Q, et al. Transcriptomic response of Escherichia coli O157:H7 to oxidative stress. Appl Environ Microbiol. 2009;75(19):6110-23.

30. Zhang X-S, García-Contreras R, Wood TK. YcfR (BhsA) influences Escherichia coli biofilm formation through stress response and surface hydrophobicity. J Bacteriol. 2007;189(8):3051-62.

31. Andersson $\mathrm{DI}$, Hughes $\mathrm{D}$. Antibiotic resistance and its cost: is it possible to reverse resistance? Nat Rev Micro. 2010;8(4):260-71.

32. Nuoffer C, Zanolari B, Erni B. Glucose permease of Escherichia coli. The effect of cysteine to serine mutations on the function, stability, and regulation of transport and phosphorylation. J Biol Chem. 1988;263(14):6647-55.

33. Hua Q, Yang C, Oshima T, Mori H, Shimizu K. Analysis of gene expression in Escherichia coli in response to changes of growth-limiting nutrient in chemostat cultures. Appl Environ Microbiol. 2004;70(4):2354-66.

34. Heyde M, Portalier R. Regulation of major outer membrane porin proteins of Escherichia coli K 12 by pH. Mol Gen Genet MGG. 1987;208(3):511-7.

35. Malki A, Le H-T, Milles S, Kern R, Caldas T, Abdallah J, et al. Solubilization of protein aggregates by the acid stress chaperones HdeA and HdeB. J Biol Chem. 2008;283(20):13679-87.

36. Stancik LM, Stancik DM, Schmidt B, Barnhart DM, Yoncheva YN, Slonczewski JL. pH-dependent expression of periplasmic proteins and amino acid catabolism in Escherichia coli. J Bacteriol. 2002;184(15):4246-58.

37. Olier M, Rousseaux S, Piveteau P, Lemâtre JP, Rousset A, Guzzo J. Screening of glutamate decarboxylase activity and bile salt resistance of human asymptomatic carriage, clinical, food, and environmental isolates of Listeria monocytogenes. Int J Food Microbiol. 2004;93(1):87-99.

38. Castanie-Cornet MP, Foster JW. Escherichia coli acid resistance: CAMP receptor protein and a $20 \mathrm{bp}$ cis-acting sequence control $\mathrm{pH}$ and stationary phase expression of the gadA and gadBC glutamate decarboxylase genes. Microbiology. 2001;2001(147):709-15.

39 Volkova W, Lanzas C, Lu Z, Grohn T. Mathematical model of plasmidmediated resistance to ceftiofur in commensal enteric Escherichia coli of cattle. PLoS ONE. 2012;7(5):36738.

40. Lu P, Ma D, Chen Y, Guo Y, Chen G-Q, Deng H, et al. L-glutamine provides acid resistance for Escherichia coli through enzymatic release of ammonia. Cell Res. 2013;23(5):635-44.

41 Seo SW, Kim D, O'Brien EJ, Szubin R, Palsson BO. Decoding genome-wide GadEWX-transcriptional regulatory networks reveals multifaceted cellular responses to acid stress in Escherichia coli. Nat Commun. 2015;6:7970.

42. Franchini AG, Egli T. Global gene expression in Escherichia coli K-12 during short-term and long-term adaptation to glucose-limited continuous culture conditions. Microbiology. 2006;152(7):2111-27.

43 McMahon MA, Xu J, Moore JE, Blair IS, McDowell DA. Environmental stress and antibiotic resistance in food-related pathogens. Appl Environ Microbiol. 2007:73(1):211-7.

44. Sinel C, Cacaci M, Meignen P, Guérin F, Davies BW, Sanguinetti M, et al. Subinhibitory concentrations of ciprofloxacin enhance antimicrobial resistance and pathogenicity of Enterococcus faecium. Antimicrob Agents Chemother. 2017:61(5):e02763-e2816.

45. Olaitan AO, Li J. Emergence of polymyxin resistance in Gram-negative bacteria. Int J Antimicrob Agents. 2016;48(6):581-2.

46. Srinivas P, Rivard K. Polymyxin resistance in Gram-negative pathogens. Curr Infect Dis Rep. 2017;19:38.

47. Kaplan JB. Antibiotic-induced biofilm formation. Int J Artif Organs. 2011;34(9):737-51.

48. Andrews S. FastQC a quality control tool for high throughput sequence data. 2014. https://www.bioinformatics.babraham.ac.uk/projects/fastqc/. 
49. Bolger AM, Lohse M, Usadel B. Trimmomatic: a flexible trimmer for Illumina sequence data. Bioinformatics. 2014;btu170.

50. Langmead B, Schatz MC, Lin J, Pop M, Salzberg SL. Searching for SNPS with cloud computing. Genome Biol. 2009;10(11):R134.

51. Robinson MD, McCarthy DJ, Smyth GK. edgeR: a Bioconductor package for differential expression analysis of digital gene expression data. Bioinformatics. 2009;26(1):139-40.

52. Mortazavi A, Williams BA, McCue K, Schaeffer L, Wold B. Mapping and quantifying mammalian transcriptomes by RNA-Seq. Nat Meth. 2008;5(7):621-8.

53. Bolstad BM, Irizarry RA, Åstrand M, Speed TP. A comparison of normalization methods for high density oligonucleotide array data based on variance and bias. Bioinformatics. 2003;19(2):185-93.

54 Livak KJ, Schmittgen TD. Analysis of relative gene expression data using real-time quantitative PCR and the $2^{-\triangle \Delta C T}$ method. Methods. 2001;25(4):402-8.

55. Wiegand I, Hilpert K, Hancock REW. Agar and broth dilution methods to determine the minimal inhibitory concentration (MIC) of antimicrobial substances. Nat Protoc. 2008;3(2):163-75.
56. EUCAST. Recommendations for MIC determination of colistin ( polymyxin E) As recommended by the joint CLSI-EUCAST Polymyxin Breakpoints Working Group. 2016, p 2016. https://www.eucastorg.

57. Beumer RR, De VJ, Rombouts FM. Campylobacter jejuni non-culturable coccoid cells. Int J Food Microbiol. 1992;15:153-63.

58. Zhu J, Mekalanos JJ. Quorum sensing-dependent biofilms enhance colonization in Vibrio cholerae. Dev Cell. 2003;5(4):647-56.

\section{Publisher's Note}

Springer Nature remains neutral with regard to jurisdictional claims in published maps and institutional affiliations.
Ready to submit your research? Choose BMC and benefit from:

- fast, convenient online submission

- thorough peer review by experienced researchers in your field

- rapid publication on acceptance

- support for research data, including large and complex data types

- gold Open Access which fosters wider collaboration and increased citations

- maximum visibility for your research: over 100M website views per year

At BMC, research is always in progress.

Learn more biomedcentral.com/submissions 